\title{
Acknowledgment of contribution towards two published articles
}

\section{Chandrashekhar Eknath Deopujari ${ }^{1}$}

Received: 3 June 2019 / Accepted: 7 June 2019 / Published online: 18 July 2019

(C) Springer-Verlag GmbH Germany, part of Springer Nature 2019

With respect to the article titled "Developing a dynamic simulator for endoscopic intraventricular surgeries" (doi: https:// doi.org/10.1007/s00381-019-04087-2), the authors would like to express their gratitude to Professor Tehemton E. Udwadia (OBE, MS, FCPS, FRCS (Eng.), FRCS (Edin.), FAMS, Hon. FACS, Hon. FARSI, Hon. FICS), Chairman, Center of Excellence for Minimal Access Surgery Training (CEMAST) \& Emeritus Professor of Surgery, Grant Medical College \& J.J. Hospital for his guidance and support during this work.

With respect to the article titled "Endonasal endoscopic skullbase surgery in children" (doi: https://doi.org/10.1007/ s00381-019-04167-3), the authors would like to acknowledge the role of Dr. Amin Kassam in operating the child of craniopharyngioma with a non-pneumatized sphenoid sinus mentioned in figure 2 of the above-mentioned article during one of our departmental workshops.

Chandrashekhar Eknath Deopujari

xcdeopujari@hotmail.com; xd.chandrashekhar11@gmail.com

Department of Neurosurgery, Bombay Hospital Institute of Medical Sciences, Mumbai, India
Also, the authors would like to acknowledge the role of Dr. Andre Grotenhuis in operating another child with craniopharyngioma during a similar departmental workshop in another year.

Remaining 47 cases have been operated by senior authors.

We would like to acknowledge the contribution of these two neurosurgeons for their continued guidance and support in developing our enoscopic skullbase surgery programme.

\section{Compliance with ethical standards}

Conflict of interest The authors declare that they have no conflict of interest.

Publisher's note Springer Nature remains neutral with regard to jurisdictional claims in published maps and institutional affiliations. 